\title{
ARABIC AS A LANGUAGE BETWEEN QUR'ANIC (SACRED) AND HISTORICAL DESIGNATIONS
}

\author{
By: Kamarudin Salleb*
}

Abstrak

Pembahasan dalam tulisan singkat ini terdiri dari tiga bagian utama. Bagian pertama akan membahas dengan singkat asal usul bahasa Arab dan datangnya agama Islam sebagai awal yang penting dalam membentuk dan mengkaji bahasa Arab. Bagian kedua akan membahas tentang perubahan dan pembaharuan sejarab dalam bahasa Arab selama periode awal Islam (sastra Arab) dan periode pertengahan, dalam arti yang luas, meliputi perkembangan ilmu pengetabuan dan sikap para cendikiawan pada saat itu. Dan pada bagian akbir, untuk memperoleh secara utuh permasalahan modern dari perubahan dan pembaharuan bahasa Arab tersebut, dua sarjana kontemporer Timur Tengah dipilih untuk memberi komentar terhadap masalah ini.

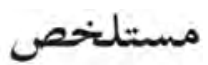

تنقسم هذه المقالة القصيرة إلى ثلاثة أجزاء؛ مقدمة :أتعرض فيها سريعاً لأصول اللغة العربية والدين الإسلامي، وذلك كنقطة محورية في تشكيل اللغة العربية .في الجزء الثاني :أسلط الضوء على عملية التغير التاريخي والتجديد الذي لحق بلى باللغة

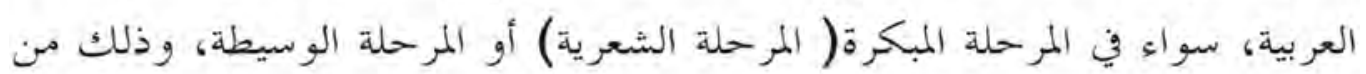

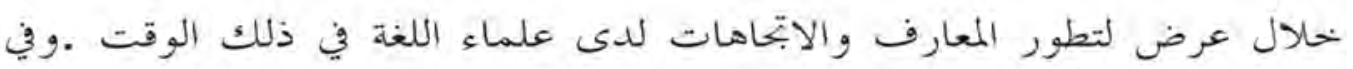
الجزيء الثالث والأخير :أحاول بشكل كلي اكتشاف أهم الإشكاليات المتعلقة بالتغير والتجديد في العربية من خلاءل العرض لآراء اثثين من الباحثين الشرق أو سطيين. بأن.

Keywords: arabic languange, history, modernization, and languange development

Department of Theology and Philosophy Faculty of Islamic Studies University Kebangsaan Malaysia. Email: kamarudinsaleh@yahoo.com 


\section{A. Introduction}

When we talk about language, it is dealing with the basic tool of human communication and interaction. Language, as a fundamental form of human expression and an instrument of a quite specific nature that to use to cope with reality of life. Language also is a central element in every human development and civilization. Language can be examined from a variety perspective concerning to the field of research and investigation. A social change in certain extent is influence by the language as an important element in cultural system. Language factor could speed up the process of development and modernization in one country. However in this paper, I am elaborating on the problems of Arabic language when pointed as a sacred by Qur'an. To begin with the presentation, I intend to grasp back slightly the roots and origins of Arabic language in history as a platform for a later explanation.

Arabic belongs to the Semitic language family, which is part of a wider HamitoSemitic family including, interalia also ancient Egyptian, within that family, it belongs to the South Semitic or South-West Semitic branch, which includes two further subgroup; South Arabian (comprising) ancient Sabaen, Mina'en, Katabanian, Hadramatia; Ethiopia (comprising) ancient Ethiopic or Ge'ez, Modern Tigne, Tigriyya, Amharic, Harari etc. On the other hand Arabic share with North-West Semitic, Hebrew, Ugaritia and Aramaic. ${ }^{1}$ Arabic as whole, thus stands between South (ProtoSemitic) and North-West Semitic having contact with both. There existed perhaps dialects intermediate between North-West Semitic and Arabic; this has been claimed for the local dialect which influenced the Hebrew Book of Job 1.

Basically Arabic is an independent language which is within the Semitic language group (along with Alexandarian, Hebrew, and the other so called Cannanite language, Aramaic and Syriac, the south Arabian dialects and the Semitic language of Ethiopia). This group is itself one of the constituents along with the Barbers dialects and ancient Libyan, an ancient Egyptian and its Coptic successor, the Kushtic languages of the Ethiopian region, and perhaps some others. Among the dead languages of this group, the most important is Biblical Hebrew, others include Babylonian and Assyrian, Syriac, and Ethiopian.

Arabic is usually classified as a). classical Arabic, b). Modern Arabic, and c). Modern Spoken or Colloquial Arabic. ${ }^{2}$ Classical Arabic had been introduced from

1 Gibb, H.A.R. (ed.), The Encyclopedia of Islam, (Leiden: E.J. Brill. Word 'Arabiyya, 1966).

2 J.A. Haywood and Nahmad, H.M., A New Arabic Grammar of Written Language, (London: Lund Humpries, 1070), pp. 1-2. 
the $6^{\text {th }}$ century A.D., if not earlier. It is the language of Qur'an and of the great writers and poets such as al-Mutannabi, Ibn Khaldun, and others. The Classical Arabic was hallowed as the vehicle of God's Revelation in the Qur'an, and was therefore not permitted to change to any marked extent. Consequently, the grammar of the 6th century Arabic still applies largely to Modern written Arabic.

The Arabic wording of the Qur'an is regarded as an essential to its holiness; as is said in many passage of the Qur'an itself: "We have sent it down as an Arabic Qur'an" (Surah Az-Zukhruf 43:3). And when we refer to the concept of sacredness and holiness, it is difficult to define in a conventional way, but those which sacred or holy is thought to contain some kind of divine power or influence, and as such its sacredness must not be violated or treated irrespectively. Accordingly, in Islam, the translations of the Qur'an are not themselves sacred scriptures but like mere commentaries. Moreover, the Muslim notion of the Qur'an (Sacred Book) is as the main authority on law, rites, the chief sources of grammar, and unapproachable model of eloquence. ${ }^{3}$

Now connecting to the language, we need to ask what effect to the problem of the cultural reception of change in Islam have had on the Arabic language. At the descriptive level we know that Qur'anic Arabic has shaped the Arabic language as a whole since the founding of Islam as a religion, and in the course of development of Islamic tenets, we have learned that according to Islam's own understanding of itself, it will not submit to any form of change (aspects which viewed as usul al-din). Does this also hold for language?. Furthermore. How can such a claim be sustained in the linguistic sphere in the face of factual reality of continual linguistic change, side by side with and analogous to social change?

In fact throughout the history along thirteenth centuries, Islam has far twice been confronted with substantial challenge, which is of interest to us here with regard to the cultural of change, specifically within the sphere of language. The first challenge arose in the Middle Age, when theologians and philosophers were beginning to respond to and adopt the cultural heritage of ancient Greece mainly at that time by scholastic theology. Arabic translations of works of Greece philosophy and science, branched off and developed into a vigorous and brilliant movement of scientific and philosophical thought which produced works of great value and originality from $3 \mathrm{rd} / 9^{\text {th }}$ to the $6^{\text {th }} / 12^{\text {th }}$ centuries. ${ }^{4}$

James Hasting (ed.), The Encyclopedia of Religion and Ethics, (Edinburgh: T\&T Clark, 1918).

4 Fazlur Rahman, Islam, (Chicago: University Press, 1979), p. 117. 
This mean the incursion of a cognitive theoretical, and rational terminology into the Islamic culture during High Islam or Golden Era of Islam (Middle Age), not only adding one more linguistic category to those already existing - the literary (poetry) and the sacred (Qur'anic Arabic) - but also stimulating substantial change and proffering alternative forms of linguistic articulation.

The second challenge is start from nineteenth century that so-called Modern confrontation between the West and the East under colonialism, which was another socio-cultural gauntlet thrown down, although this time under quite different historical circumstances. These two challenges, both the earlier effects on Arabic of the Hellenization of Islam during the classical advanced civilization phase of the Islamic Middle Age and the ongoing language change of the Modern period since nineteenth century.

Muhammad Aziz Lahbabi, the lecturer at the Muhammad V University in Rabat, the contemporary Arab thinker, has the following to say in regard to the current state of Arabic, 'our language closely bound up with our reality, 'arabiyyah adopts itself to some extent to change conditions, but sometimes it forms an obstacle to change. ${ }^{5}$ (Bassam Tibi 1991, 77). Arabic reflects both period of opening up and of stagnation in history. And today it is suffering from an inability to adopt to change, renouncing its right both to innovation and open up itself. The Arabic language is undoubtedly in need of substantial change today so that it can develop; it is subject - like anything human - to the imperatives of change.

Latter, the Arabs find themselves confronted once again with the methodological problem defining what linguistic change in fact is. The varying interpretations within linguistics of the connection between linguistic and social change. I think the Arabs should admit the entire complex of questions is still open, although insisting that change alters the grammatical structure of language less than its lexical fund and its corrrelation of meaning. Social change affects "extrallingual situations".

The grammatical structure of arabiyyah has indeed hardly changed at all in centuries. What is it that brings about this conservation of tradition in Arabic?. In the High Islamic period, this language was still capable of assimilating the philosophy of ancient Greece; but today it is not able to met the need of Modern science and technology. ${ }^{6}$ The question is that whether the sacred commitment to the language

5 Bassam Tibi, Islam and the Cultural Accomadtion of Social Change, (Boulder: Westview, 1991), p. 77.

${ }^{6}$ P.K. Hitti, History of the Arab: From the Earliest Times to the Present, (London: MacMillan, 1972), p. 689. 
would affects its capacity for expression or not?. Because of Muslim taken Qur'anic Arabic to be eternally valid, but culture is changeable and the perception of human being is shaped by certain linguistic characteristics.

This suggest another question whether a language that perceives itself as resistant to change can in fact become impediment to the cultural reception of social change, in so far as language shape human perception. In other word, how can Muslim perceive change culturally if their perception is shaped by an 'arabiyyah that is ostensibly not subject to change?

\section{B. Historical Change In Arabic}

Before going on further to disclosure on historical change in Arabic, briefly, I am looking on the impact of Islam towards the pre-Islamic poetry particularly the enrichment of vocabulary and themes in it. As far as I know, Arabic is one of the oldest literary language in the world. Long before the founding of Islam, the Arab tribes had their poets, who composed their poems in a sophisticated language, rich in vocabulary. Poetry in Arab tribes, is no more an index of cultural development in the sense used by ethnologist, than the palstic arts. Naturally, this low level in the scale of civilizations implies no congenital, inherited inferiority. It comes from the social conditions in the Arab Peninsula. ${ }^{7}$ Poetry themes circling around praise, chiding, grief, love, landscape, and camels.

Otherwise, pre-Islamic poetry had become the palladium of Arabism, the one secular proof of Arab eminence and even superiority. Pre-Islamic poetry, disdained by Muslim historian as literature of 'jahiliyya' (ignorance) is in fact among the valuable Arab literary heirlooms. And it was rapidly acquiring another end posibbly still more effective protection by being recognized as the indispensable lexicographical resource for the explication of the reconciler elements in the vocabulary of the Qur'an. ${ }^{8}$

R. Blachere divided the poetry into two types; a. poetry before year 670 A.D..50 $\mathrm{H}$. and b. poetry after year $670 / 50$. He discussed the spurious ascription to the ancient poets and ideas influenced by monotheism; he devotes a page to the Islamic poetry before $670 / 50$, and concludes that religious thought in general in the poets of the generation of Hasan ibn Thabit and Hutay'a is not directed toward meditation, but to the glorifiaction of those who made the right choice between paganism and Islam.

7 Maxime Rodinson, Mohammed, (Middlesex: Penguins Books, 1971), p.18.

8 G.E.V. Grunebaum, Aspect of Arabic Urban Literature Mostly in Ninth and Tenth Centuries, Islamic Studies Journal. Vol. 8. Num. 4. December 1969, p. 283. 
For the later period Blachere allows that the Qur'an exercises considerable influence, reflecting a penetration of religious concepts greater than before. Obviously, this happens because Arabic poetry had been exposed to Islam for more than a century and this facet clearly shown on themes and examples by poetess like Jarir (d. 731 A.D.), al-Farazdaq (d. 730 A.D.) and al-Tirimmah manipulating on Qur'anic basis.

Arabic, which gave pre-Islamic and Islamic poetess an opportunity for expression the idea was powerful and rich vocabulary, also contained the seeds for further development into a language capable of philosophical differentiation and abstraction, as the advanced Arab Islamic civilization was later to prove. As will be shown, Arab philosophers were able to shape the wealth of vocabulary of their inherited language in order to encompass of the complex social content of their time. Even the language of the Qur'an itself, which does display Hellenistic influences, despite assurances to the contrary by orthodoxy and Islamic apologetic literature, shows evidence of progress compared to the language of pre-Islamic poetry and hence also to the social condition in which it arose.

Muhammad -as Rodinson shows- "dazzled by the prestige of writing from the world of civilization and scholarship..., set his own cultivated rationality against the barbaric rationality of the Meccans. Above all, an important to remind that during the later examination of the reduction of Arabic to the language of the Qur'an in the wake of social stagnations in the Middle East is not to deny the contributions. Although the Arabic of the Middle Age, inspired by the Hellenistic philosophy, had a richer content than that of the Qur'an and was consequently more conducive to abstraction, this should not mislead Arabs into assuming that the language of the Qur'an, sacred as it was, could boast no rationality. It should suffice here to refer to Rodinson analysis of the Qur'anic ideology, rational process of argumentation were lost during the suppression of Hellenistic influences by orthodoxy". ${ }^{\text {? }}$

T.J. De Boer characterizes the basis structures of Arabic as follows;

"The Arabic language, whose wealth of vocabulary, form and cultivable qualities have been a special joy to the Arabs themselves, was eminently suited to a position of world rank. It distinguishes itself in particular, for example, from ponderous Latin and pompous Persian, through its short abstract formations, which proved to be of benefit for scientific process. It is capable of the finest nuance, but on account of its richly developed synonyms tends to lure one to deviate from the Aristotelian rule that precise science to use of synonyms is not permissible". ${ }^{10}$

9 M. Rodinson, Mohammed, (Middlesex: Penguins Books, 1971) p.131.

10 T.J. De Boer, The History of Philosophy in Islam, (London: Luzac, 1965), p. 32. 
Arabic, it further developed, facilitates the expression both the differentiated content, as well as statements devoid of content, with a mere weight of word. The former can be found in Arab philosophy, the latter in sacred language, at least it is handled by orthodoxy and in its literary form in Arabic poetry.

With the recording of the Qur'an, Arabic has been 'immortalized' to this day; had it not been recorded, there would be no longer be any Arabic today, in view of centuries of Turkish dominance and ensuing European colonization. The handling down of the Qur'an thus also meant that Arabic was kept alive in some form. With the recording of the Qur'an, however, Arabic acquired the designation of a sacred language, which continues to shape Arabic to this day. ${ }^{11}$ The attempt to go beyond Qur'anic Arabic is regarded as just as heretical today as it was in the early stage of advanced Islamic civilization in the Middle Ages, when Arab philosophers also attempted to go beyond the sacred and reduce Islam to a cultural dimension by adopting Greece philosophy.

If we explore further at the High Islam period, in order to make a comparison with the recent time, we realize that the Muslim attitude to master and activate of knowledge is quite different. In case of Middle Age's Muslim, for instance, we could see that shortly after the inauguration of the Abbasid Caliphate, translations into Arabic began to be made of Greece scientific and philosophical works. Caliph alMa'mun gave an order to organized the work of translation on a large scale. ${ }^{12}$ An instituition was set up called the House of Wisdom (Bayt al-Hikma) where books were translated and copied, and where a library was kept for reference; however the actual construction, the system itself, has an indubitably Islamic stamp; all along its metaphysical frontiers it reckons with the corresponding religious metaphysics of Islam and consciously tries to create points not only of contact but of coincidence with the latter. But this it does only in so fit as the rational Greece character of the material would allow; herein lies both its brilliant originality and it tragic fate in Islamic history; for, having failed to satisfy orthodox requirements, it was denied the passport to survival. Arab thinker who tried with the aid of Greece philosophy to break the boundaries set in the sacred language were persecuted as 'heretics'. This case, for example was happen to Ibn al-Muqaffa' (d. 759 A.D.), a Persian secretary of the Caliph of al-Mansur and the creator of Arab prose. ${ }^{13}$

11 Bassam Tibi, Islam and the Cultural..., p. 82.

12 William M.Watt, Islamic Philosophy and Theology, (Edinburgh: University Press. 1962), p. 38.

13 Ibid, p. 38. 
Conversely, some scholars and philosophers who had a liberal thinking and attitude are ready to tolerate and accept the knowledge from Greece, give a great contribution to develop and spread the science. Baghdad as a capital to the Islamic Abbasid government had been centre of knowledge development. With the help of dividing the branches of science by Islamic scholars of the tenth century into Arabic and non-Arabic one in certain extend could reduce the great confrontation between both groups. Whereas linguistic in the traditional sense, that is literally knowledge and doctrines of obligation and belief, were considers part of the Arab sphere of knowledge, all philosophical, natural sciences, and medical disciplines were treated as non-Arab branches. ${ }^{14}$

Arabic was intended to remain a sacred language, as medium for handing down the Qur'an and religious scriptures. Only in this context could linguistic remain on Arabic branch of science for Muslim orthodoxy. The coming of new words and the new meanings from greece philosophy attached to them, it was feared with some justification, could any serve to undermine the faith. Some verbal, forms, as De Boer reports, 'originating from translators of foreign works, we were abhorred as barbaric by purist language teachers. ${ }^{15}$ If we study the theology (Kalam) and philosophy in Islam will be show the gulf level of perception between those scholars. Islamic philosophy adopted the Greece theory of cognition, whereas theology served by contrast a source of legitimation for the existing form of rule.

In pointing out the conflict in Islamic history between philosophy as a secular and rational branch of knowledge and theology, in fact, the clarification was given by Islamic scholar that this conflict was not a struggle of 'pure' ideas, between rationalism and irrationalism because Qur'an give an enough room for reason. Rodinson mentioned 'the Qur'an leaves far more room for reason than the Holy Scriptures of Judaism and Christianity'. And that this rationality applies equally to post Qur'anic ideology. As Rodinson rightly in my view emphasizes, the social backwardness of the Muslim world may attributed to any number of other factors, but not to the Islamic religion. ${ }^{16}$ For this we can see that we are dealing here with the irrationality of a system of political rule that mobilized religion itself, and not with the irrationbality of the 'Holy Scriptures' as such.

14 T.J. De Boer, Târikh al-Falsafah fi al-Islâm, (Qaherah: Maktabah al-Misriyyah, 1938), p. 30.

15 Ibid.

16 M. Radinson, Marxism and Muslim World, (London: Zed Press, 1979), p. 68. 
These, scriptures, though sacred and consequently limited to specific content, have left ample room for rationality. In short, the struggle between the advocates of these two traditions in Arab Islamic history, the theologians and the philosophers, did not revolve around religion; it was concerned with two different world view, a sacred one and a rational one based on a theory of cognition. Therefore The Muqaddimah (Prolegomena) of Ibn Khaldun shows that 'we can see the great extent to which Arabic had developed into language of science and move away from the sacral Arabic of the Qur'an. ${ }^{17}$

The second stage is the collpase of the Abbasid Empire, the ensuing particularism of a variety of territorial states, and the subsequent domination by the Ottoman signified the end of this secular tradition and the restoration both religion and archaic social structures. Wolfgang Freund has summarized those impact had on the Arabic language:

Because administrative correspondence was initailly conducted in Turkish, and later in English, and French, sophisticated written Arabic was left with no social functions at all. Nothing thus stood in the way of a linguistic lapse in to the sole remaining binding element, namely the sacral text of the Qur'an. During all this, however, separate dailects were evolving among the people of the former Arab Empire, developing out of Medieval International Arabic. ${ }^{18}$

The second substantial challenge of the development is a result of European penetration of the orient in the colonial era. We have outlined the context and limits of the Hellenization of Islam when dealing with language and the conflict between Qur'anic and scientific Arabic. We have also seen that the first social cultural confrontation produced an enrichment, especially in that it was not assosiated with the establishment of a foreign power, as was the case in the recent confrontation between West and East. In the lingustic sphere, there effects of the Modern European penetration of the orient have been much more far-reaching than they were in the case of Hellenization.

Rifei'a R. al-Tahtawi (1801-1873), the Egyptian scholar who was the first Arab to study in Paris in the 1825. He return to Egypt in 1831 with the intention of disseminating what he had learned in Europe through Arabic translation, Tahtawi was forced to realize that he lacked the necessary linguistic medium.

17 Abd. Rahman Ibn Khaldun, The Muqaddimab: An Introduction to History, (London: Routledge, 1987), p. 260.

18 Bassam Tibi, Islam and the Cultural ..., p. 85. 
Centuries of stagnation in Arabic language rendered him unable to find any equivalents for the historical, socio-philosophical, and natural scientific terms of European culture.

Tahtawi was thus to obliged to begin his project by setting to work on Modernizing Arabic. He soon became aware, however, that the formal insertion of concepts lacking in Arabic using new word formations was insufficient. How could the subjects of a despotic power possibly be expected to grasp such concepts from bourgeois democratic revolutions as "liberte, humanite, fraternite". When the substance of such things did not exist in their social world?. In order to do this, it was first necessary to Modernize 'arabiyya' by their stagnant and reduced to the sacerd of the Qur'an. ${ }^{19}$

Early Arab Modernists such as Tahtawi, were full of enthusiasm with European culture. They had no doubts about sacrificing sacral Qur'anic Arabic in their effort to develop Arabic into a medium for disseminating the European ideas they had adopted. This lack of inhabition gave rise to translation movement in the nineteenth century, above all in Egypt; deficient as it may seen to Arabs today, it is nonetheless worthy of considerable historical attention.

Although great progress may be noted since that time, the central problems nevertheless still remain unsolved. The gulf between High Arabic and regional dialects (Coloquial) persists. The dialects rather virtually separate language in both vocabulary and grammatical structure, despite their non-written form and their restriction to everyday use. With the growing development of modern societies, they are becoming more and more unsuitable for the formulation of abstract, theoretical ideas. Furthermore, there are still enough apologetic thinkers resting their arguments on purist ideology and anti-philosophers tradition who bemoan the "decline of the Arabic language" as it is allegedly submerged under deluge of foreign words and new terms with European content. This attitude is typical of the largest and most influential linguistic body, al-Majma al-Lughawi al- 'Arabi (The Arab Philological Society), which is officially recognized by all Arab lands and in view of established position assumes the right to direct the renewal of the Arabic language..$^{20}$ And today, a stubborn belief persist that Arabic was predestined to be a superior language and that an Arab may acquired technical; and scientific knowledge from Europe but can never acquire useful language knowledge, a view tirelessly profound in apologetic literature.

19 Staif A.N., "The Questions of Foreign Influences in Modern Arabic Literary Criticism", in Journal of Arab Language, vol. 16, 1985, p. 109.

20 H.A.R. Gibb (ed.), The Encyclopedia of Islam, (Leiden: E.J. Brill, 1966), p. 213. 


\section{Modernization of Arabic Language and Current Situation in the Middle East}

In this part, I attempt to delineate the current conflict relating to the problem of modrenization of Arabic language which I have chosen Salama Musa and Satici Husri opinions and suggestions to solve part of the problems. Salama Musa examines the problems of Modernizing Arabic, "stating that this can only be accomplished in the context of innovation in the society, as a whole, for harking back to the ancestral cultural heritage, such as is practiced only in apologetic literature, is unproductive. We must... now create culture...' This cannot happen by evoking the cultural heritage of our ancestor, or by exhausting ourselves in the manner of al-Jahiz and Ibn Zaidun in coining cumbersome new terms, or by glorifying our old advanced culture and playing confidence tricks with our cultural origins. ${ }^{21}$

For Musa, the problem of language development and renewal falls within the context, language being 'the basis of every culture, and (because) it is absolutely impossible to bring about a dynamic, developed culture with a stagnant, decayed language. The level of development of a culture points at the same time to the level of development of the language change of that culture, and cultural progress implies renewal of language, use analysed the language problems.

Musa explicitly advocates "we cannot emphasize enough the importance of language for a people, that is, a modren language capable of assimilating the arts and science and constantly expanding its vocabulary. We mean a language that does not confine the thinker as a result of its structures, which produces him with the potential for the articulation by means of adequate terms, and which does not prevent him from comprehending scientific or philosophical content. ${ }^{22}$

Musa also vigorously attacks the Arab Philological Society for its constant attempts to cling tenaciously to the purity of Arabic, even at the price of forming inadequate Arabic words for standard European terms so far as not to have to adopt then in their original form. For Musa this kind of purism is postively strange, since the terms devised by European science have become super national, while resistance to their assimilation into Arabic create impression that 'whilst the whole world has agreed to use common terms, we alone deviate from this trend by applying terms other than those recognized throughout the world.

21 Bassam Tibi, Islam and the Cultural..., p. 91.

22 Ibid., p. 92. 
The second well-known personality in the Arab World War I is Sati'i Husri (1882-1968). He was regarded as the spiritual father of Arab Nationalism an far more influential than Musa. Husri stresses the importance of language for creating the Arab nationalism. The language form is the most important non-material link among the members of social group, giving rise to a certain way of thinking and common feelings among those who speak it, thus binding them to one another by means of a chain of intellectual and emotional relations, handed down from generation to another. ${ }^{23}$

If the language stagnates, then so does the consciouness of the group. Husri, however, wanted to start out with the revival and Modernization of Arabic, so that the Arab themselves could flourish. Husri, who had had been the benefit of a period of study in Europe and was familiar with the body of European social philosophical thought, touched on the problem of exogenous influence on a language, recognizing that every Arab 'who immerses himself in the subject matter of modern scientific disciplines inevitably begins to fell the inadequacy of the Arabic language as soon as he tries to articulate the content of science in Arabic. The fact holds despite the tame of Arabic as a language rich in content. Husri explained what he understands by the wealth of a language:

The wealth of a language can be measured neither in terms of how many word entries have been recorded in dictionaries, nor in terms of how of the number of synonyms contained in them, as dictionaries are not only all inventory of living vocabulary, but also a graveyard for dead vocabulary. This is particularly true of Arabic dictionaries, which house a munificence of vocabulary that is no longer used and has lost its value. Those who point with pride at the enormous vocabulary of a language without distinguishing between living terms and dead ones are alike to those who take pride in the size of their country withuout distinguishes between the house of living and the graeveyards of the dead. ${ }^{24}$

Although Husri, severly criticized 'arabiyya apologists, accusing them of blindness in refusing to face the backwardness of Arabic, he rightly did not go to lengths of some westernized Arab intellectulas who want to be more European than Europeans. He did consider outright Arabic to be capable of an appeal for its replacement by Europeanization of Arabic. Whereas some Arab philologists go to the lengths of

23 W.L. Cleveland, The Making of an Arab Nationalist: Ottoman and Arabism in the Life and Thought of Sati'I al-Husri, (Princeton: University Press, 1971), pp. 98-99.

24 Ibid, p.100. 
declaring 'arabiyya to be the richest language in the world, other (Westernized) authors go to extreme, asserting that Arabic is not capable of adopting the scientific terminology necessary for Arab generation. The Arab should share neither of these extreme.

Husri, then proceed to offer some preliminary suggestions for the Modernization of Arabic. First he stressed that efforts in this sphere need to be coordinated at the level of all Arab countries, all the more so because of the tendency for every written High Arabic to vary from one country to another as a result of separate development of the language. He later, called for a cross-regional body to solve those problem, a task for which he considered the Arab Philological Society unsuited. In a discussion of how to create Arabic terms as general equivalents for Modern social and natural terms, a philologist versed in the Qur'anic sciences can only prove to be eminently dispensable. $^{25}$

In the Arabiyya dispute referred to here, discussion so far focussed on the surface, scarcely departing from questions of whether or not the languages is capable of development or wheteher Arab philologist trained in the Islamic sciences are equal to the task of lingustic renewal. According to linguistics, every language is theoretically capable of development, as it is able to express all content. When a language become a sacred, however, the lingustically given capacity for expression is considerably reduced, as the language become bound to a single theme. In Islam, 'arabiyya is bound to the Qur'an and from the orthodox Muslim it cannot allowed to break the restraints set by its sacral nature. The restraints, however, are not boundaries, for they can be overcome through desacralization of the language. The liasion between Latin and Scholasticism offers a historical example at the comparative level; the demise of Scholasticism was the precursor of language development in Europe.

\section{Conclusing Remark}

My main concern particularly falls on traditional philologists, as long as their resistance to all Modernization in Arabic presents, an obstacle to further development of language keep remain. I think these philologists, ceased the pursuit of worldly sciences centuries ago and have narrowed their horizons of thought to a circle of philology and Islamic jurisprudence, ignoring all other branches of knowledge.

In this way expression in Arabic become restricted to limited content, this preventing change from entering in and further development from taking place, 
and as I point out earlier the Arabic, having managed to developed into an incipient scientific language in advenced Arab Islamic culture, has since become reduced to a sacral language impoverished in terms of abstract content.

The stagnant expressive capacity of Arabic, once a language of science, and its reduction to a sacral one, that is, to post fourteen century Qur'anic language, should not be viewed an isolated process but as a part and parcel of an all embracing process of social change. Even language renewal in the Arab Middle East cannot be understood as an isolated process. The Arab attitude and perspective towards the vitality of language renewal hardly change because of the influence of Salafiyya ideas. The Salafiyya mold of Muslim traditionalists in an all embracing one and not to be broken solely at the level of a language renewal.

Language development in the Arab culture is a metter of innovation in society as a whole, inasmuch as the problem is not simply of a sterile scientific nature but of a socio-political one. Language renewal denotes a confrontation with influential Muslim institutions and the Salafi ideology that holds sway within them, and above all an acceleration of secularization within the education sector.

\section{BIBLIOGRAPHY}

A.T., Welch. and Cachia, P. 1979. Islam: Past Influence and Present Challenge. Edinburgh: University Press.

Cleveland, W.L.1971. The Making of an Arab Nationalist: Ottoman and Arabism in the Life and Thought of Sati'I al-Husri, Princeton: University Press.

De Boer, T.J. 1938. Tarikh al-Falsafah fi al-Islam. Qaherah: Maktabah al-Misriyyah. 1965. The History of Philosophy in Islam. London: Luzac.

Eliade, M. (ed.). 1987. The Encyclopedia of Religion. New York: MacMillan.

Gibb, H.A.R. (ed.). 1966. The Encyclopedia of Islam. Leiden: E.J. Brill.

Grunebaum, G.E.V. 1969. Islamic Studies Journal. Aspect of Arabic Urban Literature Mostly in Ninth and Tenth Centuries. Vo. 8. Num. 4. December.

Hasting, J. (ed.).1918. The Encyclopedia of Religion and Ethics. Edinburgh: T\&T Clark.

Haywood, J.A. and Nahmad, H.M. 1970. A New Arabic Grammar of Written Language. London: Lund Humpries. 
Hitti, P.K. 1972. History of the Arab: From the Earliest Times to the Present. London: MacMillan.

Khaldun, Abd. Rahman Ibn. 1987. The Muqaddimab: An Introduction to History. London: Routledge.

M.M. Badawi (ed.). 1985. Journal of Arab Language. Vol. 16. The Questions of Foreign Influences in Modern Arabic Literary Criticism, by A.N. Staif.

Rahman, Fazlur.1979. Islam. Chicago: University Press.

Rodinson, M. 1971. Mohammed. Middlesex: Penguins Books.

. 1974, Islam and Capitalism. London: Allen Lane.

-1979, Marxism and Muslim World. London: Zed Press.

Tibi, B. 1981. Arab Nationalism: A Critical Inquiry. London: MacMillan.

1991. Islam and the Cultural Accomadtion of Social Change. Boulder: Westview.

Watt. W.M. 1962. Islamic Philosophy and Theology. Edinburgh: University Press. 